\title{
Using scenarios in planning a digital information service
}

\author{
Marthie G. de Kock \\ Library Services, Vista University, Private Bag X634, Pretoria, 0001 Republic of South Africa \\ dkockmg@acaleph.vista.ac.za
}

\begin{abstract}
Planning is essential in developing an electronic text centre, a digital information service or a virtual information service. It is a continuous process which is focussed on future implications generated from present decisions. Management needs certain techniques to forecast the future and plan according to how external factors will influence their decisions. Forecasters are increasingly relying on the use of scenarios to produce forecasts and to identify conditions leading to major changes in environments. Scenarios are written descriptions of possible future environments which may affect the enterprise. They cover possible developments and changes and identify future trends and events with specific emphasis on causal relationships and key decision-making aspects. The Delphi interviewing technique is discussed as a method which can be applied during the environmental scanning process. Other methods are the trend-impact and cross-impact techniques. Scenario building usually takes place within a framework in which certain methods are used to organise the scenario development process into a sequence of steps. A model specially adapted to plan scenarios for a future electronic information service is discussed. Scenarios are successful when management assumes ownership of the scenarios and put them to work.
\end{abstract}

Beplanning is noodsaaklik in die ontwikkeling van 'n elektroniese tekssentrum, 'n digitale inligtingsdiens of 'n virtuele inligtingsdiens. Dit is 'n volgehoue proses wat gefokus is op toekomstige implikasies wat uit huidige besluite voortspruit. Die bestuur het sekere tegnieke nodig om toekomstige neigings te voorspel en om te help met beplanning na gelang van die mate waarin eksterne faktore hulle besluite sal beïnvloed. Toekomsvoorspellers vertrou toenemend op die gebruik van scenarios om voorspellings te maak en toestande te identifiseer wat tot groot veranderings in die omgewing kan lei. Scenarios is geskrewe vertellings waarin die moontlike toekomstige omgewing wat 'n onderneming kan beïnvloed, beskryf word. Moontlike toekomstige ontwikkelings en veranderings word benut en toekomstige neigings en gebeure word geïdentifiseer, met spesifieke klem op oorsaaklike verhoudings en sleutelbesluitnemingsaspekte. Die Delphi-onderhoudtegniek word bespreek as metode wat by omgewingverkenning gebruik kan word. Ander metodes is die neiging- en kruisimpaktegnieke. Scenariobeplanning vind gewoonlik plaas binne 'n raamwerk waarin die ontwikkelingsproses volgens sekere stappe geskied. 'n Model word bespreek wat spesiaal aangepas is vir die beplanning van 'n toekomstige elektroniese inligtingsdiens. Scenarios is suksesvol as die bestuur verantwoordelikheid daarvoor aanvaar en dit implementeer.

A transformation or paradigm shift is currently taking place in information services. This is caused by the abundance of electronic information available via the Internet and by means of various electronic information technology. Efforts are being made to plan an environment or electronic information technology infrastructure in which to deploy all the electronic information. Managers are challenged to determine their own roles while envisioning either an electronic text centre, a digital information service or a virtual information service depending on the choice of a term.

Definite planning is essential in developing such a project. This implies that goals and objectives must be set. Plans are then generated to reach these goals and objectives while perpetual measuring of results and evaluation of success are performed during the operation period. Consequently, planning is a continuous process which is focussed on future implications generated from present decisions.

To carry out the planning task, management needs some idea of what the external factors are and how these external factors will influence their decisions. Factors such as the availability of resources, capital expenditure, changes in information technology and, increasingly, the role of government, must be considered in the development of an effective business plan.

Because the future is unforeseen and uncertain management needs techniques to forecast the future. Corporate planners and forecasters are increasingly relying on the use of scenarios to produce forecasts of future business environments and to identify conditions leading to major changes in these environments. This technique can also be applied successfully by managers of information services to forecast a future electronic information service. However, forecasts cannot reveal the future. Forecast techniques merely suggest possible future trends and events, and their interaction upon each other (Zentner 1982:12).

Scenario building is discussed as a forecast technique with which management can anticipate how current decisions made towards the development of an information 
technology infrastructure can influence the outcome of a digital information service and its future functioning.

\section{Description and purpose of scenarios}

The word 'scenario' was originally used by Italian opera composers describing the script written to summarise the opera's theme (Sunter 1992:12). The word has been adopted by the business community to describe a possible future state of an organisation's environment, considering potential developments of relevant interdependent factors in the environment (Bunn \& Salo 1993:292). Scenarios are written descriptions of possible future environments which may affect the enterprise. They cover possible developments and changes and identify future trends and events with specific emphasis on causal relationships and key decision-making aspects (Du Toit 1992:22).

However, the outcome of scenario building has shown (De Kock 1997:210) that not only is the future state of an information services environment (infrastructure) changed by relevant interdependent factors and driving forces, but the information service itself is changed because the environment influences the organisation's entire existence. Consequently, the information service and its information technology infrastructure represent the environment when a scenario is described as an imagined sequence of future events or an alternative future environment in which a manager's decisions might unfold.

The following characteristics are distinguished (Schwartz 1991:6):

- A scenario is hypothetical, because the future is unpredictable. In creating scenarios, the planner has to make certain key assumptions about the future.

- Scenarios outline the boundaries of possible change and cannot be seen as complete pictures of the future.

- Scenarios are multidimensional and holistic, because comprehensive and broad images of the future are drawn. Change is never simplistic; therefore scenarios are complex, interwoven and interdisciplinary sketches of the future.

Scenarios first emerged following World War II as a method applied for military planning. The United States Air Force tried to imagine what their opponents might do, and then proactively prepared alternative strategies. In the 1960s, Herman Kahn, who had been part of the Air Force effort, refined scenarios as a tool for business prognostication. Scenarios reached a new dimension in the 1970s, with the work of Pierre Wack and other planners at Royal Dutch/Shell, the international oil enterprise. By creating scenarios during those years they anticipated the oil price crisis, when apparently nobody else had (Schwartz 1991: 10).

\section{Methods used during scenario building}

The qualitative approach taken towards scenario building usually provides a more contextual description of how the present will evolve into the future, rather than the quantitative approach that seeks numerical precision. The qualitative approach usually tries to identify a set of possible futures, which may each be plausible, but not assured (Schnaars 1987:105) and entails the following methods:

- The deductive method in which each scenario is created by first setting the overall theme (for example optimistic or pessimistic). After that, the relevant key factors or variables are forecast in the light of each theme (Vanston et al. 1977:159-180). This approach is likely to supply internally consistent scenarios and it considers fewer possible scenarios (Schnaars 1987:119).

- The inductive method starts by identifying only a few key factors and their possible outcomes, and then develops scenarios by elaborating on a few of the plausible outcome combinations (Linneman \& Kennell 1977:141-150).

- The intuitive logics method accepts that business decisions are based on a complex set of relationships between technology, economic, political and social resources and environmental factors (Wack 1985:73-89). Most of these factors are external to the organisation, but must be understood to provide insight and improve decisions relating to product development, new ventures, capacity expansion, new technologies and business strategies (Huss \& Honton 1987:21).

\section{Techniques used to gather information}

Various techniques are used to gather information about the environmental factors on which scenarios are built. The Delphi interviewing technique is a method which can be applied during the environmental scanning process. For example, it can be used to gather information from experts on future information technology developments and events. These experts forecast their visions on innovations that may take place in the information technology environment over, for example, the next ten years. The visions are used to identify some driving forces that may influence the success or failure of an information service as a result of decisions taken during scenario planning. Political, economic and social factors are also taken into consideration because of the environmental relationship existing between these factors and the technology.

Group members are not physically together during the implementation of the Delphi technique. Iteration occurs by means of presenting a schedule or questionnaire over a number of rounds, allowing members to modify their opinions. Controlled feedback to the individual group members takes place between rounds, during which each member is informed of the opinions of the panel. This technique is applied till a consensus is reached between the group members on the questions or statements put to them.

Other major techniques which can be considered to gather information for scenario building, but include elements of a quantitative approach are the following: 
- Trend-impact analysis (Huss \& Honton 1987:23; Bunn \& Salo 1993:294). This technique represents a statistical forecasting model and a number of possible judgemental adjustments to take account of special events that may influence the trend. After a long list of trends has been identified, these trends are extrapolated into the future by applying techniques of time series forecasting to the historical data. A second list is built of events (mostly sudden) which may exert a significant impact on the forecasting trends. The main weakness of this technique appears to lie in the assessment and synthesis of the ideas.

- Cross-impact analysis (Schnaars 1987:111; Huss \& Honton 1987:24). The basic philosophy is that no development occurs in isolation but is influenced by the occurrence of other events. For example, experts are requested to provide some estimate of how likely it is that an event will occur by a given time. The question then asked is how likely it is that an event will occur given the occurrence of another event. The data are then put into a computer simulation or mathematical program. The key problem with this technique is that judgemental estimates, such as those used during the qualitative approach, cannot be influenced or controlled by mathematical plots or schemes.

\section{Phases followed during scenario building}

Scenario building usually takes place within a framework in which certain techniques are used to organise the scenario development process into a sequence of steps. These steps or phases can differ from one scenario building approach to the other. The model described in Figure 1 is adapted and applied to plan scenarios for a future digital information service.

\section{Phase 1: Identify focal issue or decisions to be made}

The first step in scenario planning is to identify the focal issues to be discussed by concentrating on institutional decisions with long-range consequences such as capital allocations, market strategies or information technology planning. The narrower the scope of the decision or strategy, the easier scenario building will be (Huss \& Honton 1987:22). A useful decision scenario should change perceptions, and must enable the relevant question(s) of strategy to be answered. Consequently, the most important task during the initial stages of scenario building is to identify the right problem(s) (which should be object and time specific), and formulate the right questions.

Method: The scope begins with a specific decision or issue (topic), and then extends towards the environment, for example: what major concerns will confront the decision makers? (Schwartz 1991:226). Key organisational issue(s) are identified. Subsequently, the long-term decisions to be made, or the focal issue to be addressed (for example, the launch and adaptation of a new product) are identified and defined.

\section{Phase 2: List key factors influencing the success or failure of decision}

Once the topic has been defined, factors that would most directly influence the outcome of the decision are identified. These factors relate to market size, economic conditions and price trends, available capital and human, material, energy and environmental resources. The more the decision makers know about these factors, the better the quality of decision making will be (Huss \& Honton 1987: 22).

Method: Define success or failure of the decision outcome, for example:

- How does the successful implementation of the decision look? What are we trying to achieve? How will we know that we have achieved it?

- How does the unsuccessful implementation of the decision look?

This leads to identification of the key factors that will directly affect the outcome of the results. The factors would normally, at least partially, be under the decision maker's control. These would be facts like customers, suppliers, the price of the product and competitors. These factors will be local or internal. Initially all factors should be listed, regardless of how insignificant they may be. Questions to be answered are:

- What will decision makers need to know when making a decision?

- What are the considerations that will shape the outcome of the decisions made?

Phase 3: Identifying the driving forces or trends that influence the key factors

Once the key factors have been listed, the third step involves listing driving forces or trends in the macroenvironment that will influence the key factors identified earlier. Driving forces are the elements that move the plot of a scenario or determine the story's outcome. These forces help to decide which factors will be significant and which factors will not (Schwartz 1991:107). They are described as the building blocks of scenarios.

A driving force is discovered by means of a thorough understanding of the factors influencing the success or failure of an electronic information service. In business these forces are usually identified by planners and analysts, outside consultants, specialised commercial information services, and general literature about the future (Huss \& Honton 1987:22). A change or trend in technology that influences the relative cost effectiveness of a company or organisation is an example of a driving force. The scenario building process therefore involves the gathering of information by way of environmental scanning. 


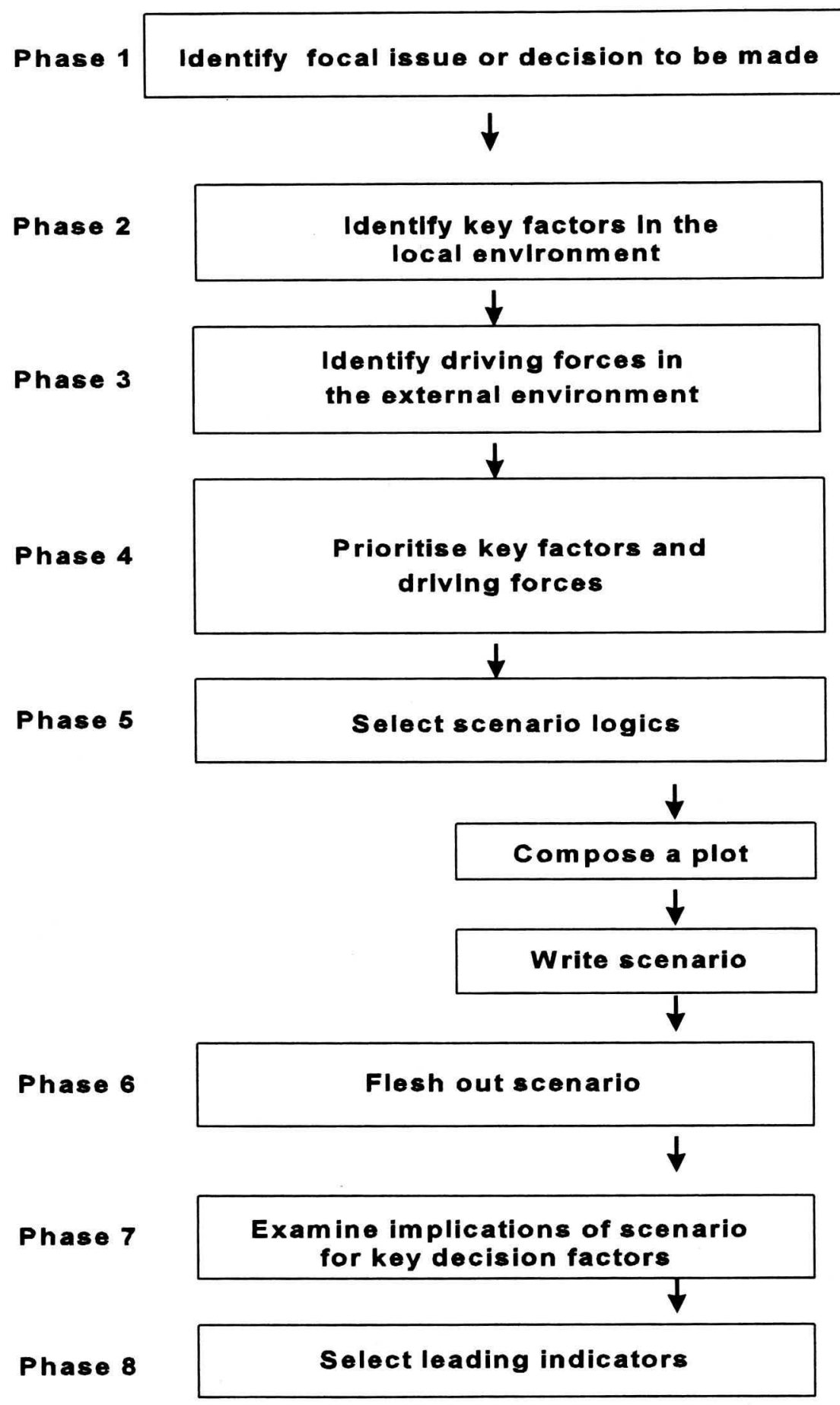

Figure 1 Model of phases followed during planning of a scenario

\section{Environmental scanning}

'Environmental scanning' is the study and interpretation of the political, economic, social and technological events and trends that influence the development of an organisation, business, industry or even a total market. These factors are all uncontrollable variables or trends that may cause change. Environmental scanning is done through a wideangle lens during which various issues are observed, but when a trend is detected, it is analysed in depth. The differ- ence between an issue and a trend can be described as follows (Venter 1995:76):

- 'Issues' are usually limited in scope and can be a temporary short-lived reaction to a social phenomenon, such as the illegal import and sales of computer parts or pirating of computer software. Issues may often be forerunners of trends, but must not be confused with trends. An issue usually has a selfrectifying character, but when it keeps recurring, it can become a trend. 
- A 'trend' is an environmental phenomenon that has adopted a structural character and therefore represents a more deep-seated phenomenon than an issue, for example, a value shift in society, a technology innovation that might be permanent, or a paradigm change. Scenarios play an important role in anticipating possible new trends.

Environmental scanning should indicate whether driving forces aid or oppose stability and whether these encourage development or lead to stagnation (Venter 1995:76). Identifying driving forces requires insight and understanding of the subject under study and a global (international and national) perspective on change processes. Research is required to cover markets, new technology, political factors and economic forces.

After identifying and exploring the driving forces, the predetermined elements and critical uncertainties of these driving forces have to be uncovered (Schwartz 1991:113). An analysis is conducted for each environmental driving force, including a discussion of the history, trends, critical uncertainties and interrelationships among environmental forces. These discussions should be short, but extensive enough to make the scenarios plausible and avoid surprises. They help to ensure that the analysis is relevant with respect to the eventual uses of the scenarios (Huss \& Honton 1987:22). These predetermined elements and critical uncertainties give structure to the exploration of the future.

\section{Predetermined elements}

Predetermined elements are 'those facts that we know we know'. A predetermined event is an event that has already occurred, but where the full consequences of the event are still to unfold in future. Predetermined elements do not depend on any chain of events and remain constant for any scenario selected (Institute for Futures Research 1991:7). These predetermined elements are likely to be true whatever the future outcome of the information services may be. The more things change, the more these predetermined elements stay the same. Predetermined elements can be one of the following (Schwartz 1991:117):

- Slow-changing phenomena, which include the growth of the population, the building of a physical infrastructure and the development of resources.

- Constrained situations, for example, the Japanese who must (and will) maintain a positive trade balance because they have millions of people who do not possess the resources to feed, clothe, warm or transport themselves.

- Inevitable collisions, for example, people who refuse to pay the government higher taxes, but at the same time refuse to sacrifice any public benefits. Once such a gridlock has been created, there is no way out.

- Pipeline elements, for example, it is known approximately how many whites will turn 60 by the year 2006 . They are already in the pipeline, that means, they have already been born and are growing older. The only uncertainty is how many are going to emigrate or pass away before then

Regardless of how much the future is circumscribed by means of these predetermined elements, there will always be variables to give an element of uncertainty in decision making (Sunter 1992:12).

\section{Critical uncertainties}

Critical uncertainties are those forces with potentially major impact on the key factors. In every plan critical uncertainties exist which the planner can use in his analysis. This implies a move from the known to the unknown. Critical uncertainties are closely related to the predetermined driving forces of a scenario, for example, the specification of key uncertainties forms part of the evaluation of the predetermined events (Institute for Futures Research 1991:7). These variables can be distinguished by questioning assumptions about predetermined elements, for example (Schwartz 1991:121):

- What could change the direction/nature/impact of a predetermined event or driving force within a certain period?

- What could cause doubt while planning a scenario?

Method: Identify driving forces or trends in the macroenvironment that influence the key factors. List those driving forces that will indirectly affect the result. These factors will all be external to the decision maker's company or organisation and will therefore be beyond his control (for example, trends in the macro economy, changes in government policy, pricing policy of vendors). List the predetermined elements that are known. List the critical uncertainties. An analysis is conducted for each environmental driving force, including a discussion of the history, trends, critical uncertainties and interrelationships among environmental forces.

\section{Phase 4: Prioritise or rank key factors and driving forces by both importance and uncertainty}

The goal is to identify two or three factors and driving forces that are most important and most uncertain (Venter 1995:84). Scenarios cannot differ over predetermined forces such as the inevitable ageing of the population, because these predetermined elements are bound to be the same in all scenarios. Unimportant factors do not need to take up time and effort in the creation of a scenario. Only factors and driving forces that score high on importance and high on uncertainty need to be considered.

Method: Identify two or three key factors and driving forces that are important and most uncertain. Rank or prioritise these key factors and driving forces by means of degree of importance for the success of the focal issue or decision and the degree of uncertainty surrounding those factors and trends. 


\section{Phase 5: Define scenario logics - describing the plot and writing the scenarios}

Scenario logics consist of organising themes, principles or assumptions that give each scenario a coherent, consistent and plausible logical underpinning. They should encompass most of the conditions and uncertainties identified in the preceding steps. Scenario logics need not cover every distinct possibility. Trial and error are usually necessary to arrive at useful scenario logics (Huss \& Honton 1987:22).

These scenario logics are used to develop a coherent understanding of the change process (alternative futures), using the building blocks of the driving forces as source material. Therefore, scenario logics represent the plot for integrating the insights gained into a coherent story or scenario (Institute for Futures Research 1991:8). The scenario logics chosen must describe the dynamics of the change process, and the change process must be communicated effectively.

\section{Composing a plot}

Whereas the driving forces (predetermined and uncertain) answered the question: what is happening and what could happen, composing the plot explains how it could happen (Institute for Futures Research 1991:8). To find plausible plots, the uncertainties that seemed so important, are used, for example, what factors might lead to success or failure?

Eventually, the plausible plots are sketched. A plot can be found by developing ideas in response to questions such as the following (Schwartz 1991:142):

- What are the driving forces?

- What is perceived as uncertain?

- What is inevitable?

- How about this and that scenario?

The goal is to select plot lines that lead to different choices for the original decision, for example: what plots or stories might make management do something different? The technique lies in deciding where in the story to start the diverging alternative futures (for the different scenarios). In scenarios for a company, or any other organisation, at least one alternative should be designed that frightens the management enough to make them think, but not so much that they lose interest or shut down.

To explain the future, scenarios describe how the driving forces might behave. The same set of driving forces might behave in a variety of ways, according to different possible plots. Scenarios usually explore two or three of these alternatives, based on the plot (or combination of plots) which are most worthy of considering (Schwartz 1991: 141).

\section{Writing the scenarios}

In this step, the scenarios that originated in the previous steps are formally described. Before this can be done, the following decisions have to be taken:
- The number of scenarios.

In the scenario approach any number of scenarios may be used. The future usually unfolds as a number of possible outcomes. It was found that normally only two or three plots or logics were used, because people's minds can cope with only two cr three possibilities at any one time (Schwartz 1991:147). In creating three scenarios, a common trap to be avoided is the tendency to design two opposite extremes and one moderate scenario. In addition, scenarios may describe alternative futures and should not be exclusively optimistic or pessimistic. They should present opportunities and threats to the company or organisation.

- How to name scenarios.

There are three approaches to the naming of scenarios (Venter 1995:85):

$\square$ The optimistic-pessimistic approach (e.g. High Road-Low Road).

$\square$ The thematic approach (e.g. Armageddon, Siege or Checkmate).

$\square$ An approach where scenarios are referred to as scenario $\mathrm{A}, \mathrm{B}$ and $\mathrm{C}$ according to the sequence in which they were created.

- What type of scenario should be chosen.

The role that a scenario will play in the planning process will determine the type of scenario to be used. A scenario can be a static image (photo) or an end-state scenario describing how the situation may look over five or ten years.

Method: Driving forces (predetermined forces and uncertainties) are used as source material to build a plot. Scenario logics describe the dynamics of the change process. The change process is communicated effectively. Composing the plot explains how the change (alternative futures) unfold. The scenario is described in story format. The number and type of scenarios are decided upon and named.

\section{Phase 6: Fleshing out the scenarios}

Fleshing out or elaborating the scenarios involves combining scenario logics with environmental analyses. The scenarios are written so that the analysis provides more focussed information about key factors for decisions (Huss \& Honton 1987:22). While the most important factors and forces determine the logistics that distinguish the scenarios, fleshing out the skeletal scenarios is accomplished by returning to the list of key factors and forces or trends previously identified in Phases 2 and 3. This means that each key factor and driving force is given some attention in each scenario.

The content of scenarios is determined by the uncertainty. In some instances it could be the future course of the market (or organisation) itself that presents questions, in others it is the organisation's timely response to strategic manoeuvres. In each the content of the scenario would be different. 
Method: In creating the scenarios, the factors and forces not selected in Phase 5 are also receiving attention. These lesser factors are incorporated into the scenario. Possible effects of the different factors are evaluated. Results are built into a narrative or story, the actual scenario creating phase.

In composing a scenario, the guiding principle is to keep it as simple as possible. Complex scenarios with numerous variables and preconditions are difficult to communicate and understand. If a scenario cannot align the world of perceptions of management with the world of reality, the exercise is not worthwhile.

\section{Phase 7: Implications of scenarios for key decision factors}

Once the scenarios have been developed in some detail, it is necessary again to return to the focal issue or decision, identified in Phase 1, to determine what implications each scenario has for the key decision factors. For example:

- How does the decision look in each scenario?

- What vulnerabilities have been revealed? (Schwartz 1991:231).

The implications of each scenario for the organisation should be analysed. The strategic gap between reality and where the information service wants to position itself in future (its preferred or desired future) is used to determine future actions (Venter 1995:86).

Method: Compare the original decision made with the narratives created. How does the decision look in each of these scenarios? What vulnerabilities are uncovered? Will the decision look good in all or just in some scenarios?

\section{Phase 8: Identify and select leading indicators}

Once the different scenarios have been fleshed out and their implications for the focal issue been determined, a few indicators are identified which can be monitored in an ongoing way. These indicators are used to serve as evidence that conditions are moving towards one scenario rather than another (Institute for Futures Research 1991:10). If these indicators are carefully selected, the information service may gain in knowing what the future holds, and how the future is likely to affect strategies and decisions made in the different organisations (Schwartz 1991:232). This implies that as history unfolds, it is important to see which of the scenarios created is nearest to the mark. To enable management to do this, it is necessary to highlight the leading indicators of each of the different scenarios. Indicators can be distinguished by asking the following questions (Huss \& Honton 1987:22):

- Does information about the future validate the original assumptions and support the strategies or proposed decisions?
- What do the scenarios imply for the design and timing of particular strategies?

- What threats and opportunities do the scenarios suggest?

- What critical issues emerge from the scenarios?

- What special cases deserve to be addressed by specific contingency plans?

- What kind of flexibility and resilience do the scenarios suggest that are necessary from a campaign planning perspective?

- What factors and forces deserve monitoring in the light of information gathered from the scenarios?

\section{Evaluation of a scenario planning process}

Evaluation of a scenario planning process consists of comparing the assumptions of the selected strategy, programme or project with the scenario results. Using scenarios is similar to rehearsing the future. A person runs through the simulated events as if he were already living them. Therefore, each scenario has to be simple, dramatic and bold enough to cut through the complexity and aim directly at the heart of an individual's decision. The role of scenarios is to arrange the factors so that the decision is illuminated, instead of obscured.

The actual test is whether the manager's behaviour has changed because the future is seen differently. An effective scenario should usually change behaviour (Schwartz 1991: 214). Good scenarios are both plausible and surprising, and have the power to break old long-term stereotypes. Scenarios are successful when the management assumes ownership of the scenarios and put the scenarios to work (Schwartz 1991:232). A willingness to face uncertainty and understand the driving forces requires an almost revolutionary transformation in a large organisation. This transformation process is as important as the development of scenarios (Wack 1985:75).

\section{Conclusion}

Scenarios are applicable to the planning needs of managers of information services because management faces major information technology investment decisions within an environment of great uncertainty. Consequently, scenarios provide a tool for forecasting long-range, complex and highly uncertain business environments. However, scenarios should be re-evaluated and revised on a regular basis including the external forces that influence the success or failure of decisions made.

Scenarios are successful if they help managers to acquire more insight into the risks, vitality and flexibility of various decisions and supply management with a strong position from which to operate. 
This implies that a scenario should have credibility that includes

- comprehensiveness (a broad coverage of relevant factors),

- consistency (the outcomes of different variables and trends do not intuitively conflict with each other, or with the background information (Bunn \& Salo 1993: 299), and

- logic.

Scenarios should be easy to understand and easy to use. They should contain facts and information that are relevant to the management of an information service. These scenarios should be incorporated into any of the information services planning documents. This will provide the staff insight into various outcomes once they have to make choices or have to decide on a specific future development or implementation.

An example of the various steps followed and methods used during the scenario building process is attached as Table 1.

\section{References}

Bunn, D.W. \& Salo, A.A. 1993. Forecasting with scenarios. European journal of operational research, 68:291-303.

De Kock, M.G. 1997. An information technology infrastructure for resource sharing in South African academic information services. DLitt et Phil thesis, Rand Afrikaans University, Johannesburg.
Du Toit, A.S.A. 1992. Gebruik van scenarios as 'n beplanningstegniek. South African journal of library and information science, 60(1):17-23.

Huss, W.R. \& Honton, E.J. 1987. Scenario planning - what style should you use? Long range planning, 20(4):21-29.

Institute for futures research, University of Stellenbosch. 1991. Scenario building workshop. Compiled by P.H. Spies. Stellenbosch: University of Stellenbosch.

Linneman, R.E. \& Kennell, J.D. 1977. Shirt-sleeve approach to long-range plans. Harvard business review, (55): 141150.

Schnaars, S.P. 1987. How to develop and use scenarios. Long range planning, 20(5):105-114.

Schwartz, p. 1991. The art of the long view: planning for the future in an uncertain world. New York: Doubleday.

Sunter, C. 1992. The new century: quest for the high road. Cape Town: Human \& Rousseau/Tafelberg.

Vanston, J.H., Frisbie, W.P., Lopreato, S.C. \& Poston, D.L. 1977. Alternate scenario planning. Technological forecasting and social change, 10:159-180.

Venter, T.P. 1995. Environmental scanning and scenarios, in General management, ed. J. Kroon. Pretoria: Kagiso Tertiary: 73-89.

Wack, P. 1985. Scenarios: uncharted waters ahead. Harvard business review, (5):73-89.

Zentner, R.D. 1982. Scenarios, past, present and future. Long range planning, 15(3):12-20. 
Table 1 Scenario planning and methods

\begin{tabular}{|c|c|c|c|}
\hline Phase 1 & Phase 2 & Phase 3 & Phase 4 \\
\hline $\begin{array}{l}\text { Identify focal issue or de- } \\
\text { cision to be made. (Key } \\
\text { organisational issue). }\end{array}$ & $\begin{array}{l}\text { List key factors in the local or } \\
\text { micro-environment influencing } \\
\text { the success or failure of } \\
\text { decisions. }\end{array}$ & $\begin{array}{l}\text { List driving forces or trends in } \\
\text { the macro-environment that } \\
\text { influence key factors. }\end{array}$ & $\begin{array}{l}\text { Rank key factors and driving } \\
\text { forces according to both } \\
\text { importance and uncertainty. }\end{array}$ \\
\hline $\begin{array}{l}\text { Method: } \\
\text { 1. Begin with a specific } \\
\text { issue (topic). } \\
\text { 2. Expand towards environ- } \\
\text { ent, e.g. What are the } \\
\text { decisions to be made that } \\
\text { will have a long-term } \\
\text { influence on the well-being } \\
\text { of the organisation? } \\
\text { 3.The Issue that distinguishes } \\
\text { a scenario must make a } \\
\text { difference to the organisa- } \\
\text { tion. }\end{array}$ & $\begin{array}{l}\text { Method: } \\
\text { List facts about customers, } \\
\text { suppliers, competitors: } \\
\text { - What will decision makers } \\
\text { want to know when making } \\
\text { choices? } \\
\text { - What will be seen as } \\
\text { success or failure? } \\
\text { - What are the considerations } \\
\text { that will shape those } \\
\text { outcomes? }\end{array}$ & $\begin{array}{l}\text { Method: } \\
\text { 1. List the forces behind the } \\
\text { micro environmental factors. } \\
\text { 2. Some are predetermined, } \\
\text { e.g. demographics, some } \\
\text { are highly uncertain. } \\
\text { 3. Research required may } \\
\text { cover markets, new tech- } \\
\text { nology, political factors, eco- } \\
\text { nomic forces. }\end{array}$ & $\begin{array}{l}\text { Method: } \\
\text { 1. Rank Phases } 2 \text { and } 3 \text { on } \\
\text { the basis of two criteria: } \\
\text { - Degree of importance for } \\
\text { success of focal issue or } \\
\text { decision identified in } \\
\text { Phase } 1 \text {. } \\
\text { - Degree of uncertainty } \\
\text { surrounding those factors } \\
\text { and forces. } \\
\text { 2. Identify the two or three } \\
\text { factors or forces that are } \\
\text { most important and most } \\
\text { uncertain. }\end{array}$ \\
\hline
\end{tabular}

\begin{tabular}{|c|c|c|c|}
\hline Phase 5 & Phase 6 & Phase 7 & Phase 8 \\
\hline $\begin{array}{l}\text { Define scenario logics: } \\
\text { - Describe the plot. } \\
\text { - Write the scenarios. }\end{array}$ & $\begin{array}{l}\text { Flesh out or elaborate on the } \\
\text { scenarios. }\end{array}$ & $\begin{array}{l}\text { Determine the implications of } \\
\text { each scenario on the key } \\
\text { decision factors. }\end{array}$ & $\begin{array}{l}\text { Identify and select leading } \\
\text { indicators. }\end{array}$ \\
\hline $\begin{array}{l}\text { Method: } \\
\text { 1. Use driving forces } \\
\text { (pre determinants and un- } \\
\text { certainties) as source } \\
\text { material to build a plot. } \\
\text { 2. Composing the plot, } \\
\text { explain how the change } \\
\text { (alternative futures) } \\
\text { should happen. } \\
\text { 3. Describe scenarios in } \\
\text { story format. } \\
\text { 4. Decide on the number of } \\
\text { scenarios. } \\
\text { 5. Name the scenarios. } \\
\text { 6. Decide on what type of } \\
\text { scenario to create. }\end{array}$ & $\begin{array}{l}\text { Method: } \\
\text { 1. Less important and less } \\
\text { critical factors should be } \\
\text { used to elaborate on the } \\
\text { descriptions. } \\
\text { 2. These should be in- } \\
\text { corporated into scenario. } \\
\text { 3. Evaluate the possible } \\
\text { effects of the different } \\
\text { factors. } \\
\text { 4. Build results into a nar- } \\
\text { rative. }\end{array}$ & $\begin{array}{l}\text { Method: } \\
\text { 1. Compare the original } \\
\text { decision made with the } \\
\text { narratives created: } \\
\text { - How does the decision rate } \\
\text { in each of these scenarios? } \\
\text { - What vulnerabilities are } \\
\text { uncovered? } \\
\text { - Will the decisions look } \\
\text { 'good' in all or just some of } \\
\text { the scenarios? }\end{array}$ & $\begin{array}{l}\text { Method: } \\
\text { Select indicators to serve as } \\
\text { evidence that conditions are } \\
\text { moving towards one scenario } \\
\text { rather than another. }\end{array}$ \\
\hline
\end{tabular}

